Bangladesh Journal of Anatomy January 2009, Vol. 7 No. 1 pp. 19-21

\title{
Morphological Study of the Kidney in Relation to Age
}

\author{
Hamida Khatun ${ }^{1}$, Zakia Sultana², Nur-A-Farhana Islam³, GM Kibria ${ }^{3}$, Tawfiq- E-Elahi Chy ${ }^{5}$
}

\begin{abstract}
Objective: The study was done to standardize the morphological data of kidney in relation to the age of person.
\end{abstract}

Materials and methods: The study was done on kidneys collected from 50 postmortem cases, age from 11 years to 80 years, during the period of July 2005 to December 2005 in the department of Anatomy, M.A.G. Osmani Medical College, Sylhet. Kidneys were collected with legal permissions from the authority in charge of the morgue of Forensic Medicine department of M.A.G. Osmani Medical College, Sylhet. Among the cases 32 were male and 18 female. The kidneys were fixed in 10\% formosaline. The weight, length, breadth and thickness were recorded.

Result: Data were collected in 3 groups, lower age (11- 25 years), middle age (26-40 years) and higher age (41-80 years) groups.

The mean weights of the kidney in 3 groups were found as $88.53 \mathrm{gm}, 95.25 \mathrm{gm}$ and $91.62 \mathrm{gm}$ respectively. Similarly the mean lengths were recorded as $8.12 \mathrm{~cm}, 9.12 \mathrm{~cm}$ and $8.73 \mathrm{~cm}$. the mean breadth were 4.46 $\mathrm{cm}, 4.31 \mathrm{~cm}$ and $3.58 \mathrm{~cm}$. the mean thickness in these three groups were $1.72 \mathrm{~cm}, 2.19 \mathrm{~cm}$ and $1.48 \mathrm{~cm}$ respectively.

Conclusion: It can be concluded that the gross values of different dimensions of the kidney, except the breadth, increases up to the age of 40 years. With further advance of age they are gradually decreased. The breadth was found greater in lower age group.

Key words: Morphology of kidney, age

\section{Introduction}

Normal kidney measures about $12 \mathrm{~cm}$ in length, 6 $\mathrm{cm}$ in breadth, $3 \mathrm{~cm}$ in thickness and weighs about $130 \mathrm{gm}^{1}$. Kidney loses its functioning cells with age that do not have the ability to divide ${ }^{2}$. From $4^{\text {th }}$ decade up to $8^{\text {th }}$ decade of life the human kidneys lose approximately a fifth of their weight ${ }^{3}$. Kidneys with length less than $8 \mathrm{~cm}$ are regarded as contraindication for intervention of renal arterial disease $e^{4}$. It is found from the available publications that human kidneys have been extensively studied by various investigators but very few research works

1. Assistant Professor, Department of Anatomy, North East Medical College, Sylhet.

2. Associate Professor, Department of Anatomy, Sylhet MAG Osmani Medical College.

3. Assistant Professor, Department of Biochemistry, North East Medical College, Sylhet.

4. Professor, Department of Anatomy, Enam Medical College, Savar, Dhaka.

5. Assistant Registrar, Surgery unit-III, Sylhet MAG Osmani Medical College.

Correspondence: Dr Hamida Khatun have been performed in Bangladeshi people. We depend on the data published in textbooks and literatures, which come from the subjects of different races and from the individuals under different geographic and climatic conditions. So research on kidney of Bangladeshi population to understand its morphological as well as structural basis is very important.

\section{Materials and methods}

The present study was carried out on 50 human kidneys of Bangladeshi people aged from 11 years to 80 years. Among them 32 were male and 18 were female.

The kidneys were collected from apparently fresh dead bodies that underwent medicolegal examination from July 2005 to December 2005 in the morgue of the department of Forensic Medicine, M.A.G. Osmani Medical College, Sylhet. Written permission was obtained from the ethical committee of the college to collect the specimen for study. Each specimen was tagged with an identification 
number. Age of bodies was recorded in a separate register book. For measurement of different parameters, left kidneys were chosen randomly, because it was found that there was no gross morphometric difference between right and left kidneys. The specimens were divided into 3 groups; a) lower age group $A$ (11-25 years), b) middle age group B (26-40 years) and c) higher age group C (41-80 years) (table-I). The specimens were washed thoroughly with tap water and gently squeezed to remove the blood clots from the Lumina of blood vessels. Specimens were then kept in $10 \%$ formosaline for fixation and preservation.

Formalin fixed specimens were kept in tap water overnight to wash out excess formalin to minimize the irritation of eyes and nasal mucosa. Specimens were than taken in a tray and associated fat, fascia, nerves and other unwanted tissues were removed. Then the weight of the kidney was measured by means of a dietetic balance and results were recorded in gm. The length was measured from upper pole to lower pole. The breadth was measured at the level of the hilum. The thickness was measured at the region of maximum antero-posterior diameter. Length, breadth and thickness were measured with the help of slide calipers graduated in $\mathrm{mm}$. Photographs were taken as needed.

\section{Observation and Results}

Results are summarized in tabulated form (tableII). The weight of kidneys of all these 3 groups ranged from 60 to $125 \mathrm{gm}$ and the mean weight was 92.08 $\mathrm{gm}$. The range of length was 7 to $11.5 \mathrm{~cm}$ and the mean was $8.99 \mathrm{~cm}$. the range of breadth was 3 to $6.5 \mathrm{~cm}$ and the mean was $4.08 \mathrm{~cm}$. The range of thickness was 1.14 to $2.87 \mathrm{~cm}$ and the mean was $1.78 \mathrm{~cm}$.

\section{Discussion}

In this study the mean weight of the kidney was found maximum in group $B(95.25 \mathrm{gm})$ and minimum in group $A(88.53 \mathrm{gm})$. The difference is minimum between group $A$ and group $C$. These findings indicate that the weight of the kidney increases its maximum level in and around 40 years of age. Thereafter it decreases slightly with increasing of age. Alam 5 observed the weight of kidneys increase with the increase of age particularly up to 40 years. Anderson and Brenner ${ }^{3}$ reported that renal mass increases from about $60 \mathrm{gm}$ at birth to more than $400 \mathrm{gm}$ during $3^{\text {rd }}$ and $4^{\text {th }}$ decades. By the $9^{\text {th }}$ decade it declines to less than $300 \mathrm{gm}$. Basmajian ${ }^{6}$ stated that, in adult, the kidney weighs about 130 to $150 \mathrm{gm}$. Mullick ${ }^{7}$ worked on 21 pairs of human kidney in Bangladeshi population and found the average weight of the kidneys was $113 \mathrm{gm}$. It is evident from the present study that the mean weight of the kidneys (92.08 gm) in Bangladeshi people is considerably lower in comparison to that of western people. This might be because of their higher body weight as well as greater body surface area in western population.

Sinnatamby ${ }^{1}$ found the normal kidney measures more than $12 \times 6 \times 3 \mathrm{~cm}$. Mullick ${ }^{7}$ observed the average measurements of Bangladeshi human kidney are $9.9 \mathrm{~cm}$ in length, $4.6 \mathrm{~cm}$ in breadth and $3.7 \mathrm{~cm}$ in thickness. But in the present study the values are $8.99 \mathrm{~cm}(7-11.5 \mathrm{~cm}), 4.08 \mathrm{~cm}(3-6.5 \mathrm{~cm})$ and 1.78 $\mathrm{cm}(1.14-2.87 \mathrm{~cm})$ respectively (figs. $1,2,3)$. This lower value in present study might be due to formalin fixation. The mean length and thickness are maximum in group $B$ but the breadth is maximum in group A. Observed findings, except the breadth, gradually increase or decrease in measurement in proportionate to the weight of the kidney. It is also obviously clear that the kidneys of Bangladeshi people are shorter, narrower and thinner in comparison with those of western people.

Table-I

Grouping of the samples in relation to age of the persons

\begin{tabular}{lcc}
\hline Group & $\begin{array}{c}\text { Range of age } \\
\text { in year }\end{array}$ & $\begin{array}{c}\text { Number of } \\
\text { specimen }\end{array}$ \\
\hline A & $11-25$ & 15 \\
B & $26-40$ & 16 \\
C & $41-80$ & 19 \\
\hline Total & $11-80$ & 50 \\
\hline
\end{tabular}


Table-II

Values of different morphological parameters in respect of age groups

\begin{tabular}{lccc}
\hline Parameters & Groups & $\begin{array}{c}\text { Range of } \\
\text { values }\end{array}$ & $\begin{array}{c}\text { Mean } \\
\text { value }\end{array}$ \\
\hline Weight (gm) & A $(n=15)$ & $60-120$ & 88.53 \\
& B $(n=16)$ & $60-125$ & 95.25 \\
& C $(n=19)$ & $60-120$ & 91.62 \\
Length (cm) & A $(n=15)$ & $7.6-10$ & 8.12 \\
& B $(n=16)$ & $7.8-11.5$ & 9.12 \\
& C $(n=19)$ & $7-10$ & 8.73 \\
Breadth (cm) & A $(n=15)$ & $3.5-6.5$ & 4.46 \\
& B $(n=16)$ & $3.2-5.3$ & 4.31 \\
Thickness (cm) & A $(n=19)$ & $3-4$ & 3.58 \\
& $B(n=16)$ & $1.2-2.2$ & 1.72 \\
& C $(n=19)$ & $1.14-1.97$ & 1.48 \\
\hline
\end{tabular}

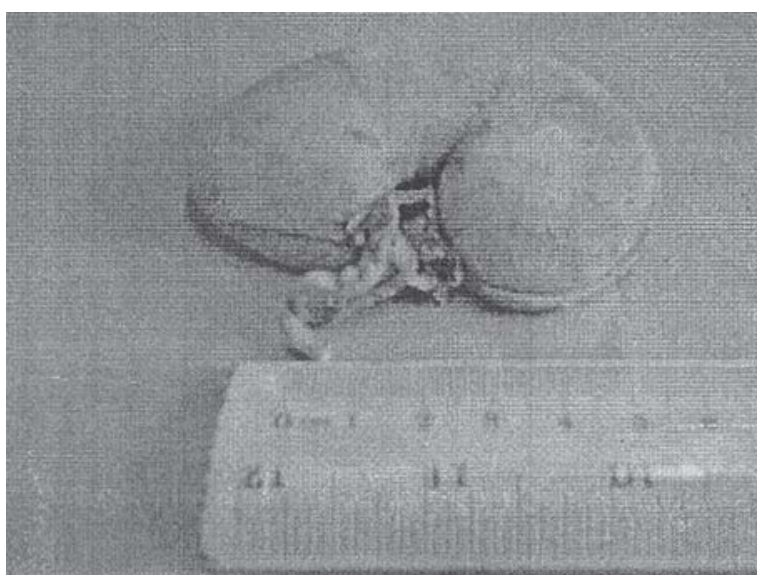

Fig.-1: Photogrtaph of the kidney collected from the youngest person in the study

\section{References}

1. Sinnatamby CS. Last's anatomy regional and applied. $10^{\text {th }} \mathrm{ed}$. Edinburg: Churchill Livingstone 1999:p.267-280.

2. Anderson S, Brenner BM. Effects of aging on the renal glomerulus. A M J Med 1986;80: 435-7.

3. MacLachlan MSF. The aging kidney. Lancet 1978;11:143-6

4. Mikael, Mark. Renal artery intervention - an invasive radiologist's approach. Saudi Journal

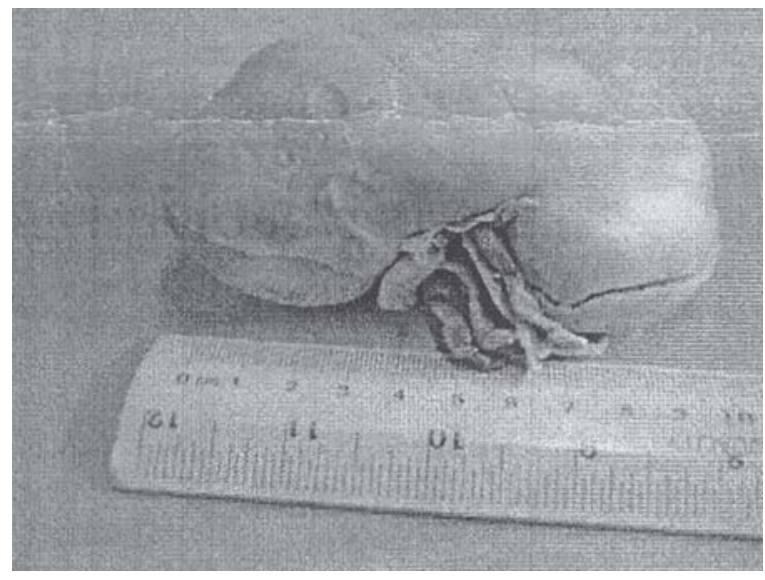

Fig.-2: Photograph of the kidney having highest weight in the study. This kidney is from group $B$.

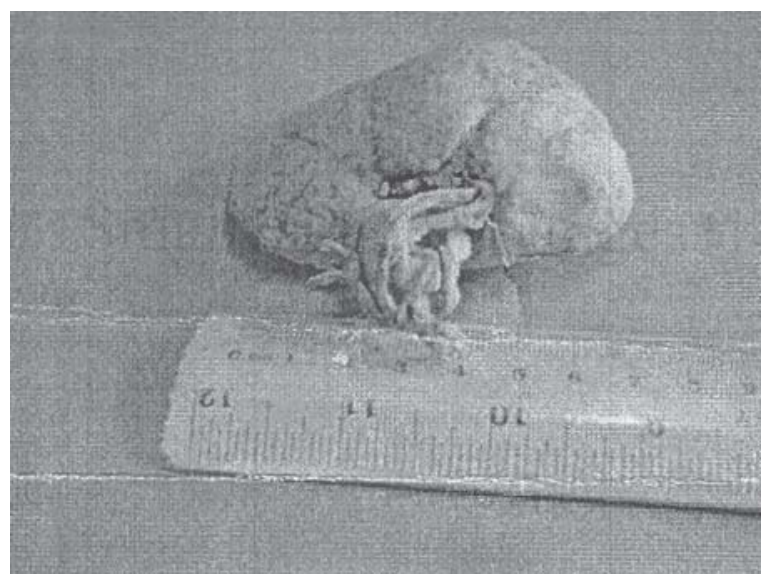

Fig.-3: Photograph of kidney collected from the oldest person in the study

of kidney diseases and transplantation 2005;16(2):181-192.

5. Alam MZ. Gross morphological and histological features of kidneys in Bangladeshi people [thesis] 1994: Department of Anatomy, IPGM and R.

6. Basmajian JV, Slonecker CE. Grant' method of anatomy. $11^{\text {th }}$ ed. Baltimore: William and Wilkins 1989:p.182-187.

7. Mullick $\mathrm{MH}$. The arterial pattern of human kidney. Journal of Pakistan medical association 1970;XX(3):77-83. 